\title{
Static and Fatigue Shear Characteristics of Rubber-Metal Laminat- ed Bearings Partially Using High Tearing Rubber at Their Edge under Compression
}

\author{
Kazuya Okubo (Doshisha University, Kyo-tanabe 610-0394 Japan), Susumu Kuroda (Nitta \\ Corporation, Ikezawa Yamato-Kohriyama 639-1085 Japan) and Toru Fujii (Doshisha University, \\ Kyo-tanabe 610-0394 Japan)
}

The effect of the partial use of high tearing strength rubber at the edge of rubber-metal laminated bearings was examined. The static or cyclic fatigue shear loads were applied to the circular rubber bearing subjected to compressive load at room temperature. The specimens having a chambered edge at the laminating steel plates were also used.

The crack initiation was significantly delayed due to the use of high tearing strength rubber under static load, regardless of the edge shape of the steel plates and compressive load. For conventional rubber-metal laminated bearings fabricated by one kind of rubber, the edge shape affected the nominal shear strain at crack initiation in case of static low compression.

The shear modulus of the specimens with high tearing strength rubber under cyclic loading was slightly lower than that of conventional one. The visco-elastic tangential loss at $5 \mathrm{~Hz}$ vibration was slightly decreased with an increase of the number of cyclic loading. This change was not related with the material and the magnitude of compressive load. The tangential loss for the specimen with high tearing strength rubber was larger than that of conventional one, and was affected by the compressive load at high frequencies $(10 \mathrm{~Hz}$ and $20 \mathrm{~Hz})$.

(Received on June 17, 1999)

Key Word: Rubber bearing, Shear, Compression, Tear strength, Static strain, Fatigue shear modulus, Tangential loss

\section{1. 緒言}

建物を地震による振動から絶縁する手段として 用いられ，比較的薄いゴム材料と鋼板とがその厚 み方向に積層されて形成される積層ゴム支承は, ゴム材料の非圧縮性および超弾性の能力を積極的 に利用した工業製品の一つである。
通常，積層ゴム支承では，鉛直方向すなわち積 層した方向の岡性は上部に搭載される物体の重量 を支えるために大きく，積層方向と直交する方向 の剛性は免震効果を生み出すために前者と比べて 極めて小さい.このような積層ゴム支承に比較的 大きなせん断変形を与えると, 実際の破壊は, せ ん断方向に見て物体の端部付近から発生するのが 


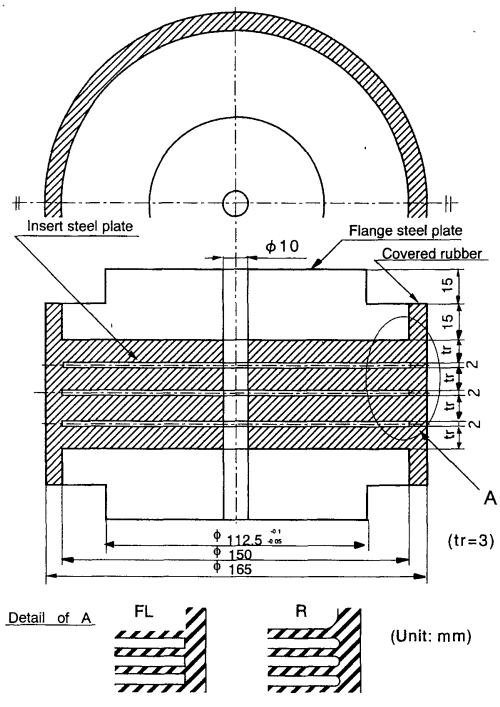

(a) Traditonal type (with main rubber).

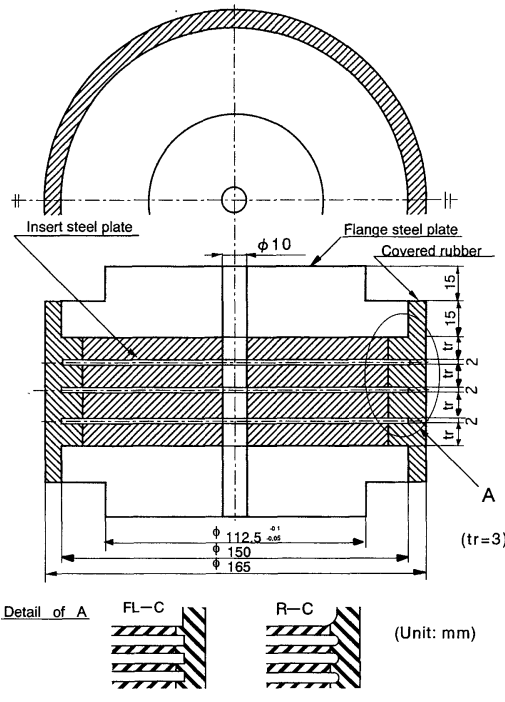

(b) With high tearing strength rubber type.

Fig. 1 Geometry of specimen.

一般的であり，設計上，端部は重要な部位の一つ であるといえる。

ゴム／鋼板からなる通常の免震用積層ゴム支承 の強度あるいは弾性に関する研究例としては, 深 堀 ${ }^{1,2)}$ や, 赤坂 $ら^{3)}$, 藤田ら ${ }^{4,5)}$ によって詳しく 報告され，その力学的なメカニズムが明らかにさ れている。また著者ら ${ }^{6)}$ もその端部形状の違いに ついて検討し, 端部から発生する破壊過程の違い を論じた。これらから考えると，積層ゴム支承に 用いるゴム材料の材料構成が積層ゴム支承の破壊 を左右する主要因の一つであるといえるが，破壊 の起点付近に対して異なる材料構成の配置を積極 的に行い，それによる力学的な能力向上を論じた 報告例は，著者らの知る限り見られない。

そこで本研究では，積層ゴム支承の端部に引裂 強度の高いゴムを配置した特殊な積層ゴム支承を 試作し，まずその圧縮せん断荷重下における静的 なクラックの発生限界を調べた。圧縮荷重は 2 水 準とし，静的試験では鋼板の端部に R 面の加王を 行ったものも比較検討した。次に，繰り返しせん 断荷重下におけるせん断剛性の変化と, 疲労荷重 を中断した際の小振動に対する損失係数 (損失正 接 $\tan \delta)$ を測定し，それらに対する端部への異種 ゴムの配置の効果を調べた。 小振動の周波数は 4 種類とし，疲労荷重を受けた免震用積層ゴ么支承
の損傷状態を把握する目的で測定した。それぞれ 得られた結果は，すべてのゴム部が一種類のゴム 材からなる通常の積層ゴム支承の結果と比較し， その力学的な効果を評価した。

\section{2. 試験 片}

Fig. 1 に試験に使用した円柱状試験片の形状を 示す。試験片の形状は実際の積層ゴム支承を縮小 モデル化したものである.フランジおよび内挿鋼 板を同軸線上に配置するため，試験体中心部には 貫通孔を設けた。

使用したゴムの物性值を Table 1 に示す。ゴ ム材料は，ゴム材料の引裂強度 (Tear Strength) を変化させる観点から，天然ゴム系の 2 種類とし た。本報では，引裂強度の高いものを高引裂ゴ ム，低いものを主ゴムと呼ぶ．前者と後者の引裂 強度の違いは，JIS K 6301 における A 法および B 法いずれでも約 1.6 倍である.

試験片の材料構成は 2 種類とし，すべてのゴム 部分を前述の主ゴムとした通常の構成の試験片 と，半径位置が $67.5 \mathrm{~mm}$ より外側のゴム部に高 引裂ゴムを使用した 2 種類の試験片構成を用い た。後者の試験片には記号 “C”を付けて区別 し，以下単に，“端部に高引裂ゴムを使用した試 験片”と呼ぶ. 
Table 1 Material properties of rubbers

\begin{tabular}{|c|c|c|c|c|c|}
\hline & & Unit & Standard for test & Main rubber & $\begin{array}{l}\text { High tearing } \\
\text { strength rubber }\end{array}$ \\
\hline \multicolumn{2}{|c|}{$\begin{array}{l}\text { Static shear } \\
\text { modulus }\end{array}$} & $\mathrm{MPa}$ & JIS K6386-61 & 0.872 & 0.921 \\
\hline \multicolumn{2}{|c|}{$100 \%$ modulus } & $\mathrm{MPa}$ & JIS K6386-3 & 1.76 & 1.57 \\
\hline \multicolumn{2}{|c|}{$200 \%$ modulus } & $\mathrm{MPa}$ & JIS K6386-3 & 3.82 & 3.04 \\
\hline \multicolumn{2}{|c|}{$300 \%$ modulus } & $\mathrm{MPa}$ & JIS K6386-3 & 6.76 & 5.19 \\
\hline \multicolumn{2}{|c|}{ Tesile strength } & $\mathrm{MPa}$ & JIS K6386-3 & 17.1 & 31.7 \\
\hline \multicolumn{2}{|c|}{ Failure strain } & $\%$ & JIS K6386-3 & 570 & 740 \\
\hline \multicolumn{2}{|c|}{$\begin{array}{l}\text { Stiffness Hs } \\
\text { (JIS, A) }\end{array}$} & $\mathrm{Hs}$ & JIS K6301-5 & 56 & 55 \\
\hline \multirow{2}{*}{$\begin{array}{c}\text { Tear } \\
\text { strength }\end{array}$} & JIS, A & $\mathrm{MPa}$ & JIS K6301-9 & 12.4 & 20.4 \\
\hline & JIS, B & $\mathrm{MPa}$ & JIS K6301-9 & 5.10 & 8.33 \\
\hline
\end{tabular}

また，内挿鋼板の端部にアール $(\mathrm{R})$ 加工を施し た試験片には " $\mathrm{R} "$ ，通常の切断加工面の鋼板を 有するものには“FL”の記号をつける。例之 ば," $\mathrm{R}-\mathrm{C}$ 試験片” とは，鋼板端部の形状が $\mathrm{R}$ 形状で，かつ端部に高引裂ゴムを使用した試験片 を意味する。

ゴム材は鋼板およびフランジ部に加硫接着し た. 試験片の外径は $\phi 165 \mathrm{~mm}$, 各せん断層の直 径は $\mathrm{D}=\phi 150 \mathrm{~mm}$, 厚みは $\mathrm{t}=3 \mathrm{~mm}$, 内抻鋼板 の枚数は 3 , ゴムが鋼板で拘束されている面積と 自由表面積の比で定義される形状係数 $\mathrm{S}(=\mathrm{D} / 4$ t)は 12.5 である。

\section{3. 試 験 方 法}

\section{1 静的試験方法および試験装置}

すべての試験は室温実験室環境で行った。

Fig. 2 に試験機，および試験片の取り付け状態 を模式的に示す。静的試験では，一定の圧縮荷重 下にて二つの試験片に同時にせん断負荷が行える 自作の油圧式圧縮・せん断試験機を用いた。試験 片には，積層方向の圧縮荷重を与えた後にジグを 介してせん断変位が加わるようにした。試験片の 積層方向に加える圧縮圧力は, 一般の免震用積層 ゴム支承の設計指 針7)を参考に $5[\mathrm{MPa}]$ と $10[\mathrm{MPa}]$ の 2 種類とした。公称せん断ひずみ速 度は $150[\% / \mathrm{min}]$ とした。 せん断方向の変位によ り発生する反力 (以下，単にせん断荷重と呼ぶ)を 4 枚のUずみゲージを貼った自作のロードセルに

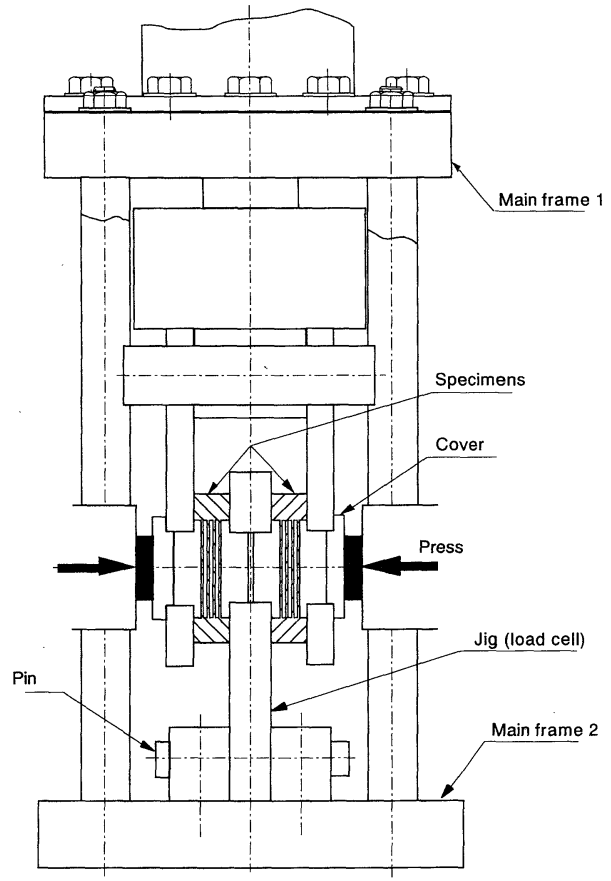

Fig. 2 Static shear compression testing machine.

より測定し，同時にせん断変位を変位計により測 定した。試験システムを Fig. 3 に示す。ゴム材 は一度変形を加えると初期剛性が低下する現象 (mullins 効果) ${ }^{8-10)}$ が起こるので，静的せん断負 荷は $80 \%$ の公称せん断ひずみを 10 回繰り返し与 


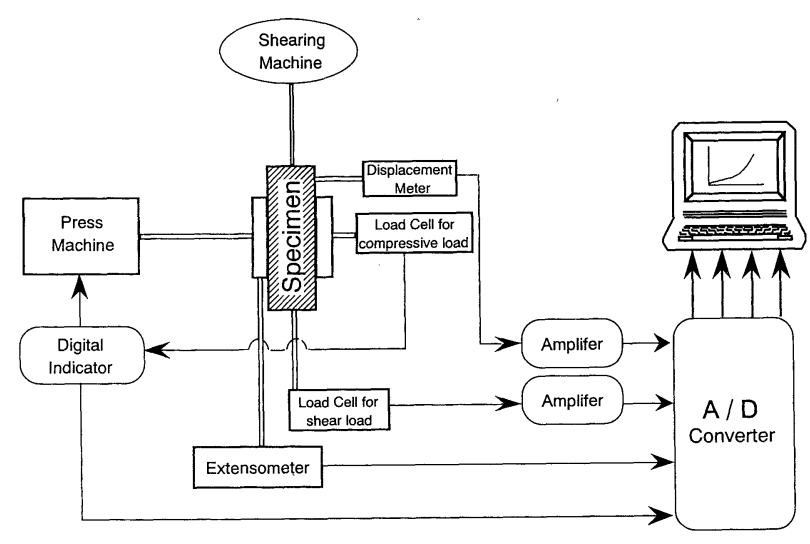

Fig. 3 Diagram of testing system.

\section{えた後に行った。}

静的試験では，各条件ごとの試験片数を 6 と し，破断まで任意の段階で負荷を中断し，試験片 を試験機から取り外して切り出し，内部状態を観 察した。本研究では，端部より発生するき裂の有 無を評価した。

\section{2 疲労試験方法および試験装置}

疲労試験におけるせん断荷重の負荷には, 電気 油圧サーボ疲労試験機 (定格 $49[\mathrm{kN}]$ ) を用いた。 疲労試験における積層方向の圧縮圧力は, 静的試 験同様， $5[\mathrm{MPa}]$ および $10[\mathrm{MPa}]$ とした。せん 断方向への繰り返し荷重の印加は荷重制御のもと で行い, 繰り返し最大せん断荷重は $25[\mathrm{kN}]$, 荷 重波形は完全両振りの三角波, 周波数は $0.2[\mathrm{~Hz}]$ とした. 発生するせん断変位は変位計を 用いて測定し，コンピュータにて処理した。

また，粘弾性的性質の変化を調べるために，疲 労試験を中断し, 試験体に小振動のせん断荷重を 与えて粘弾性特性を調べた。少振動荷重は最大值 $4[\mathrm{kN}]$ のサイン波で周波数は $1,5,10,20 \mathrm{~Hz}$ とした.この荷重範囲の公称せん断応力と公称せ ん断ひずみの関係はほぼ線形であった。

\section{4.試験結果および考察}

\section{1 静的挙動}

Fig. 4 に, 積層方向に圧縮圧力を受けながらせ 几断変形寸る試験片の，公称せん断応力一公称せ ん断ひずみ線図の一例を示す。図における縦軸は せん断荷重をせん断層の公称幅である内抻金属板 の面積で除して求めた公称せん断応力を，横軸は (a) compression $5 \mathrm{MPa}$

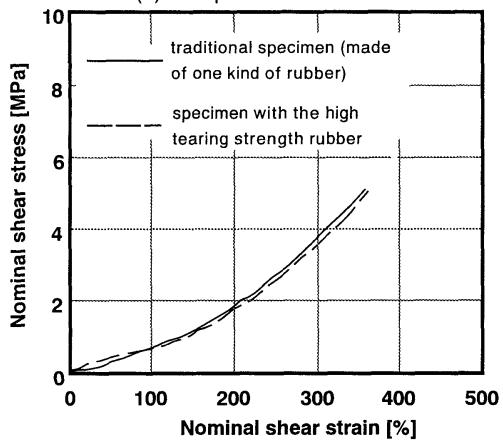

(b) compression $10 \mathrm{MPa}$

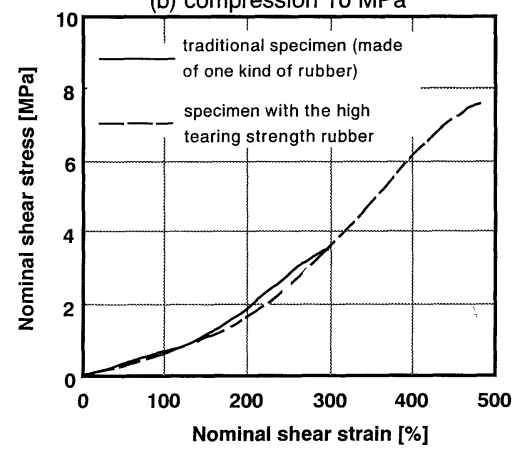

Fig. 4 Experimental S-S curves under static shear load with compressions.

フランジ間の相対変位をゴム層の総厚さで除した 公称せん断ひずみを示す.図では圧縮圧力 5 およ び $10[\mathrm{MPa}]$, 試験片の種別は端部の形状が "FL" である試験片の結果例を示した．図中の 2 曲線は, 主ゴムを一様に使用した通常の試験片 "FL 試験片" と，端部に高引裂ゴムを使用した 試験片 "FL-C 試験片” の違いを表す。図より分 かるように，"FL-C 試験片” の端部のゴム層の 幅は試験片の全幅に比べて小さいので, 高圧縮圧 力下 $(10[\mathrm{MPa}])$ で破断時の公称せん断ひずみが 前者に比べて大きくなること以外，公称せん断応 カー公称せん断ひずみ線図における両者の違いは 比較的小さい.

Fig. 5 に，静的せん断荷重下における破断直前 の試験片内部に生じるき裂の状態の一例を示す. 写真は $10[\mathrm{MPa}]$ の圧縮圧力下で $479 \%$ の公称せ ん断ひずみを与えた後に試験片を試験片の中心線 で切断した観察写真を示す。図より分かるよう に，鋼板とゴムとの境界の端部付近に生じたき裂 


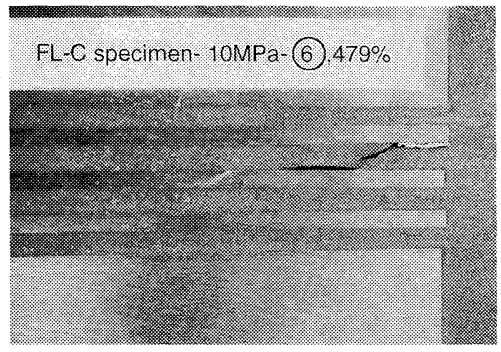

Fig. 5 Example of the internal crack under static shear load with compressions.
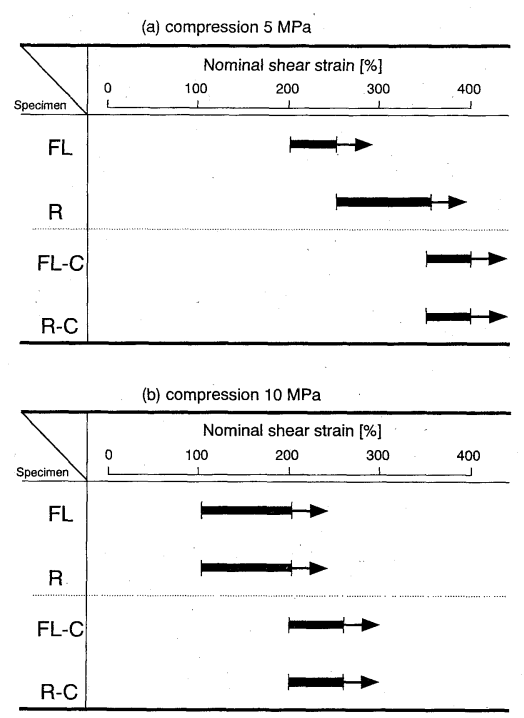

Fig. 6 Comparison of the nominal shear strain at crack initiation in different static compressions.

(図中の白く見える部分)が，鋼板層とゴム層の境 界に沿って進展する様子が見られる。同様な現象 は他の条件でも観察された。

Fig. 6 に，このき裂の発生時期と, 試験片の形 状および構成との関係を示す。四における横軸は 与えた公称せん断ひずみを示し，縦の項目は試験 片の種別を示す。太線はき裂の発生が実験上で観 察された範囲を示す。なおこの範囲よりも大きな 公称せん断ひずみを与えるとき裂は必ず発生する と考之, 矢印以降の範囲は負荷の中断による観察 の対象から除外した。 また，図中の (a),(b) は積 層方向に与えた圧縮圧力の違いを表す。図より分 かるように，圧縮圧力が(a) $5[\mathrm{MPa}]$ よび(b)
$10[\mathrm{MPa}]$ のいずれの場合も，また鋼板の端部形 状が FL およびRのいずれの場合も，記号 “C” を付けた試験片のほうが端部にき裂を発生する公 称せん断ひずみは大きい。このことから端部に高 引裂ゴムを使用することは, 積層ゴム支承のき裂 の発生を抑止する効果があるといえる，ただしそ の違いの比率は, 積層方向に与える圧縮圧力が大 きいと低下するといえる。

また，主ゴムを一様に使用した通常の試験片 (記号：FL,R)の場合, 特に低圧縮圧力の際は, 鋼板の端部形状の違いにより, き裂が発生する公 称せん断ひずみに違いが見られるが，端部に高引 裂ゴムを使用すると(記号：FL-C,R-C)，その 值は鋼板の端部の形状にほとんど影響されなくな る.このことは, 端部に力学的性質の異なるゴム を適切に配すれば, 端部の機械加工の精度に強度 が依存されにくい積層ゴム支承が実現できること を意味する。

\section{2 疲労挙動}

繰り返しせん断荷重下における公称せん断応力 と公称せん断Uずみ線図の変化の一例を Fig. 7 に示す。困では積層方向の圧縮圧力が 5 [MPa]，鋼板の端部形状は "FL 試験片”の結果 の例を示す.図中の $\mathrm{n}$ は荷重の繰り返し数を示 し，ひずみの原点をずらして図示した。なお残留 ひずみはほとんど見られなかった。罒より分かる ように, 繰り返し数の増加に伴い, 曲線の傾きと ヒステリシスループの大きさが変化していること が分かる。

そこで，せん断剛性の変化に対する端部のゴム 材質の違いの影響を調べるために, Fig. 8 に剛性 低下曲線を示す。困における縦軸は繰り返し負荷 時の最大公称せん断応力を最大公称せん断ひずみ 

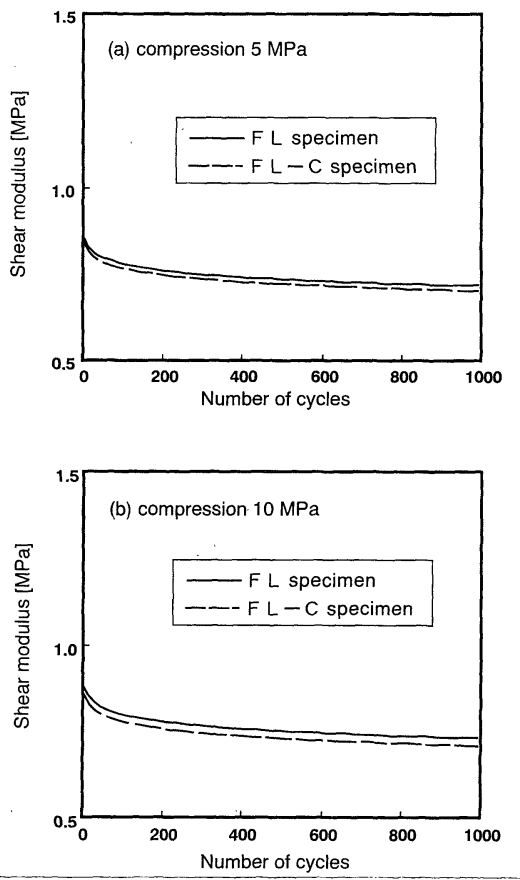

Fig. 8 Shearing modulus decay diagram under compression.

で除した值を，横軸は繰り返し数を示す。困中の (a)，(b) は積層方向に与之た圧縮圧力の違いを表 す。眓より分かるように，也ん断剛性は初期の繰 ク返し数の段階で急激に低下しその後一定の值に 平衡する。この挙動は，ゴム材料に関する研 究8,11)で説明されている現象と一致する。同じ圧 縮荷重条件での端部のゴム材質の違いについて比 較すると, 繰り返し数全域において, 端部に高引 裂ゴムを使用した FL-C 試験片のせん断剛性は, 主ゴムを一様に使用した通常構成の FL 試験片の それに比べて若干小さい.

Fig. 9 に疲労荷重を受けた試験片がもつ粘弾性 特性の変化を立体的に示寸。図における鉛直軸は 疲労荷重を中断しその試験片に小振動荷重を与え た際の変位の時間遅れから計算した損失係数(損 失正接 $\tan \delta)$ を示し, 水平面内の紙面左斜女方向 の軸は繰り返し数, 右斜め方向の軸は与えた小振 動の周波数である. 図中の (a), (b) は積層方向に 与えた圧縮圧力の違いを表す.

図より分かるように，与えた小振動の周波数が 1 および $5 \mathrm{~Hz}$ 程度の低い周波数の場合, 損失係
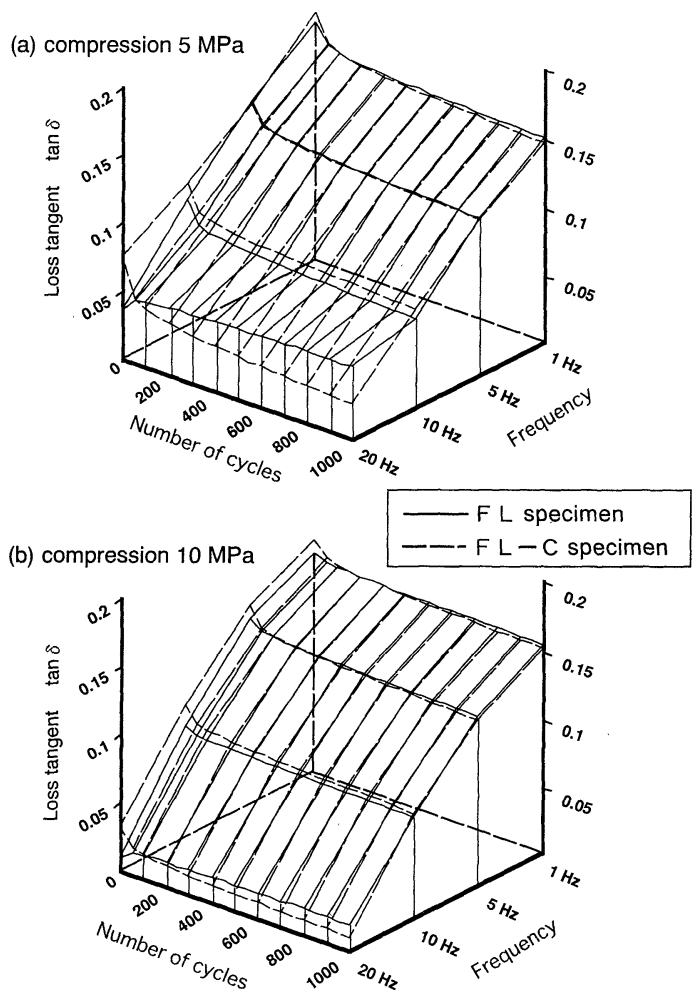

Fig. 9 Tangential loss after cyclic fatigue shear load with compression.

数 (損失正接 $\tan \delta) の \mathrm{FL}$ 試験片と $\mathrm{FL}-\mathrm{C}$ 試験片 との結果には大きな差違は見られない.しかし特 に小振動の周波数を $20 \mathrm{~Hz}$ とすると，端部に高 引裂ゴムを使用した FL-C 試験片の損失係数(損 失正接 $\tan \delta)$ は，通常の FL 試験片のそれよりも 疲労繰り返し数の増加に伴い大きく低下寸る. 損 失係数(損失正接 $\tan \delta$ ) は材料のもつ粘弾性的性 質とともに疲労により生じる内部損傷にも起因す ると考えられ，本結果は端部に高引裂ゴムを用い ることにより疲労に伴う内部損傷が抑制されたこ とを意味すると思われる。

ここで，Fig. 10 に疲労試験終了後の FL 試験 片より切り出した試験片の中心線上での断面写真 を示す．図中の黒い影の部分に，き裂状の損傷が 確認できる。また，Fig. 11 にそのき裂面の SEM (電子顕微鏡) 写真を示す。図より分かるように, SEM 写真では繰り返し荷重によりき裂面が摺動 したような微細な凹凸状の損傷が見られる。一方 


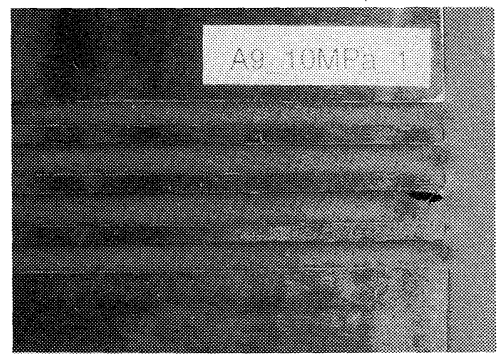

Fig. 10 Example of the internal crack under fatigue shear load with compressions.

$\mathrm{FL}-\mathrm{C}$ 試験片では，このようなき裂状の損傷は全 く観察できなかった。

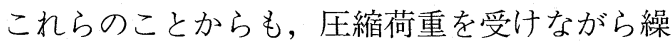
り返しせん断荷重を受ける積層ゴム支承の端部に 高引裂ゴムを部分的に用いることは，その端部か ら生じる疲労損傷の発生を抑止する効果があると いえる。

\section{5. 結言}

積層方向の圧縮荷重を受けながら，積層方向と は直交する方向の静的あるいは疲労せん断荷重を 同時に受ける積層ゴム支承の端部に引裂強度の高 いゴムを配置する効果に関して，以下のような結 論を得た。

(1)静的負荷の場合, 積層方向の圧縮圧力にかか わらず，また鋼板の端部形状がフラット $(\mathrm{FL})$ お よびアール面 $(\mathrm{R})$ のいずれの場合でも，端部に高 引裂ゴムを用いた試験片のほうが, 端部にき裂が 発生する公称せん断Uずみは大きい.ただしその 違いの比率は, 積層方向に与える圧縮圧力が大き いと低下する。

(2)鋼板の端部形状の違いについて見ると, 主ゴ ムを一様に使用じた通常の試験片の場合, 特に低 圧縮圧力の際，き裂が発生する公称せん断ひずみ は鋼板の端部形状に依存するが, 端部に高引裂ゴ ムを使用すると(記号： $\mathrm{FL}-\mathrm{C}, \mathrm{R}-\mathrm{C}$ ), その值 は鋼板の端部形状にほとんど影響されない。

(3)疲労損傷状態を把握するため疲労荷重を中断 し小振動を与えると，端部に高引裂ゴムを使用す る試験体の小振動に対する損失係数 (損失正接 $\tan \delta)$ は, 通常の試験体のそれよりも疲労繰り返 し数の増加に伴い大きく低下する. 更に通常の試

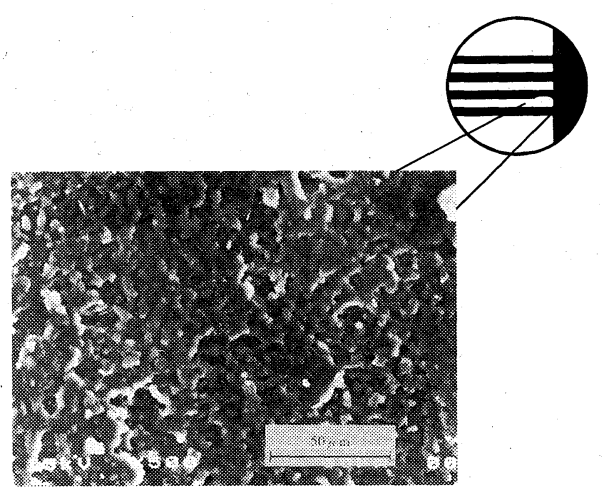

Fig. 11 SEM photograph of internal crack under fatigue shear load with compressions (FLspecimen, $5 \mathrm{MPa}$ ).

験体では微細な凹凸面を有するき裂状の疲労損傷 が発生するが，前者ではき裂状の損傷の発生が抑 制される。

(4)以上の事実より，圧縮荷重を受けながら繰り 返しせん断荷重を受ける積層ゴム支承の端部に高 引裂ゴムを部分的に用いることは，その端部から 生じる静的および疲労損傷の発生を抑止する効果 があるといえる。

\section{6.おわりに}

本研究を遂行するにあたり, 李宣昌氏(同志社 大学大学院, 研究当時) が尽力を尽くした.

\section{参 考 文 献}

1) 深堀美英：日ゴム協誌，68，388(1995)

2) Seki, W., Fukahori, Y., Iseda, Y., Matunaga, T. : Rubber Chem. Technol., 60, 856 (1987)

3 ）赤坂 隆, 長谷川淳, 小針真美：日ゴム協誌，64, 201 (1991)

4) 藤田隆史, 藤田 聡, 鈴木重信, 芳沢利和：日本機械 学会論文集 $(C$ 編 $) ， 53 ， 71(1990)$

5 ) 藤田隆史, 池永雅良, 下田郁男: 日本機械学会論文集 (C編)，57，76(1991)

6) 大窪和也, 李 宣昌, 黒田 進, 藤井 透: 材料, 48, 9, 1017 (1999)

7 ) 免震構造設計指針：社団法人日本建築学会編 (1989)

8 ）上田明男：日ゴム協誌，53，607(1980)

9 ) Bueche, F.: J. App. Polym. Sci. 10, 107 (1960)

10) Bueche, F. : J. App. Polym. Sci. 15, 271(1961)

11）藤本邦彦, 右田哲彦, 鈴木浩也：日ゴム協誌, 54, $53(1981)$ 